\title{
Chapter 5 \\ The Construction of Citizenship in Kazakhstan Between the Soviet Era and Globalization
}

\author{
Almash Seidikenova, Abdeljalil Akkari, and Aitkali Bakitov
}

\begin{abstract}
From the Soviet era to the present day, conceptions of Kazakh citizenship have undergone continuous transformations, notably due to changes in political regimes, shifts in the demographic composition, and economic fluctuations. Despite its tumultuous history, Kazakhstan has managed to forge a flexible approach to citizenship and relatively peaceful relationships between the county's different ethnic groups. In today's post-independence nationhood, Kazakhstan may represent a unique case of citizenship building in the context of globalization.

The first part of this chapter addresses the ambiguities concerning conceptions of citizenship during the Soviet era, which were marked not only by deportations, evacuations, voluntary and involuntary migrations but also by a rhetoric that depicted Kazakhstan as the 'Promised Land' benefiting from the Soviet Union's friendship. The second part analyzes citizenship building following the county's independence in 1991 that could be described as a subtle blend of Soviet heritage and renewed Kazakh national identity. The third part will focus on the transformations driven by the country's economic globalization and new migratory flows. Finally, the fourth part suggests that Kazakhstan's trilingual policy may open up new prospects for global citizenship education (GCE).
\end{abstract}

Keywords National identity $\cdot$ Ethnicity $\cdot$ Language diversity $\cdot$ Globalization

\footnotetext{
A. Seidikenova $(\varangle) \cdot$ A. Bakitov

Al-Farabi Kazakh National University, Almaty, Kazakhstan

e-mail: Almash.Seidikenova@kaznu.kz
}

\section{A. Akkari}

Faculty of Psychology and Educational Sciences, University of Geneva, Geneva, Switzerland e-mail: abdeljalil.akkari@unige.ch 


\section{Introduction: Citizenship Before and Under the Soviet Regime}

In order to understand the complexities of Kazakh national and cultural identity it is important to trace its origins. One of the most important aspects of Kazakh society is its division into three zhuz (territorial and tribal division), namely Uly (Great), Orta (middle) and Kishi (little). Despite what their names suggest, this division is not directly linked to the size of each zhuz. In addition, the three zhuz are composed of different ethnic groups and tribes.

These territorial and tribal divisions go back to the sixteenth century and relate to the Kazakh Khanate ${ }^{1}$ heritage. As suggested by Arslan (2014), the splitting into $z h u z, u r u g h^{2}$ and tribes remain an important feature of Kazakh society today. For instance, when Kazakhs meet for the first time they will ask the person's last name and where they are from ( "kay elsin"?). The answer indicates the zhuz and urugh of the person. The importance given to this sense of identity is associated to the Kazakhs' deep respect for their ancestry and heritage, as illustrated in the proverb: 'he who does not know his ancestors of the past seven generations is ignorant'.

The division into three zhuz is related to the country's geographical regions and the ancient nomadic routes: the territory of the Great zhuz is located in Zhetisu (SouthEast Kazakhstan); the people of the Middle zhuz traditionally occupy the territory of Central, North and East Kazakhstan as well as a small portion of the Southern territory; Kazaks that belong to the Little zhuz are located in Western Kazakhstan (Massanov et al. 2000).

Throughout history, the territory of present-day Kazakhstan was crossed by various populations, including Tartar and Mongolian tribes, and experienced numerous invasions. In the thirteenth century, Genghis Khan's troops invaded central Asia that became part of the Mongol Empire known as the Golden Horde (Grousset 1970). In the fifteenth century, the Golden Horde was fragmented into khanates, which included the Kazakh Khanate (located approximately in the territory of modern-day Kazakhstan) (Zardykhan 2002).

During this period, the region experienced internal conflicts linked to "tribalism" (discord and internal disputes among tribes belonging to the different zhuz) that hampered its development and significantly weakened its defense capacity. This changed in the eighteenth century when Ablai-Khan ${ }^{3}$ united the three zhuz to strengthen the state, fight against external enemies, preserve the land and develop the country (Bakitov and Jumanova 2016).

In the middle of the eightieth century, the Russian Empire gradually expanded across the Kazakh steppes. Following the "Great October Socialist Revolution" in 1917, the Soviets imposed communist ideology that profoundly transformed Kazakh society. This period was marked by the forced settlement of nomadic populations,

\footnotetext{
${ }^{1}$ The Kazakh Khanate is considered as the origin of the Kazakh nation. It was founded in the middle of fifteenth century when several tribes under the rule of sultans Janybek and Kerey were united.

${ }^{2}$ Extended family lineage or clan.

${ }^{3}$ A Kazakh khan of the Middle zhuz.
} 
industrialization and urbanization, which created a new Kazakh Soviet culture (Bakitov and Jumanova 2016).

Under the Russian regime, citizens were at first ruled over by a Tsarist autocracy followed by a theoretically more progressive communist regime. Because of old rivalries between the Russian and Ottoman empires and the Kazak's strong cultural and linguistic ties with Turkey, the Soviet Socialist Republic wanted to implement a policy of assimilation in Russian culture in Kazakhstan. For this reason, they undertook a "civilizing" mission that resulted in exile, famine and loss of cultural identity for the nomadic Kazak people who had occupied for thousands of years the vast steppes of the Central Asia Mountains. Furthermore, many Germans, Koreans, Kurds and Chechens were deported to Kazakhstan followed by Russians, Ukrainians, Tartars and many others who were encouraged to settle in the region. Consequently, the Kazakhs found themselves in a minority position in their own territory. Kazakhstan, during the soviet period, was the only country in Central Asia that was in a position of demographic inferiority in relation to Slavic populations, particularly in cities where the indigenous population was in the minority (Bakitov and Jumanova 2016).

Nevertheless, in comparison to the Tsarist era, the communist regime was theoretically slightly more in favor of the recognition of Kazakh nationality within the Soviet Union. Kazakhstan was portrayed as a land of friendship between people and at the same time experienced an unprecedented economic boom. Factories, cities and numerous infrastructures were built during the Soviet period resulting in some improvements in the standard of living and education of Kazakhs.

During this period, every citizen of the Soviet Union was identified as belonging to an ethnic or national group while required to demonstrate absolute loyalty to the Soviet state as a whole (not to a particular ethnic group, which was condemned as nationalistic) (Olcott 1995). Thus, being a citizen in Kazakhstan during the Soviet period created ambivalent feelings; on the one hand, the cultural domination of Russia devalued the Kazak language and denied the population their cultural rights; on the other hand, the friendship between people advocated by the Soviet system allowed Kazakhs to assimilate Russian values and culture, in particular the language and way of life. It is equally true that the Republic of Kazakhstan was distinguished by the fact that it once served as a showcase of the Soviet regime for its social and economic programs. The term "Kazakhstan" appeared in official discourse to encourage a sense of citizenship pride among the inhabitants of this originally multi-ethnic republic (Kuškumbaev 2011).

It is important to note that caution should be exercised when using terms such as "nationality" and "citizenship" in Kazakhstan. As Davenel (2013) emphasizes in his book "Cultural Renewal and National Diversity in Kazakhstan": the term "nationality", from Russian "nacional'nost", refers to ethnic identity and is not related to the notion of citizenship. The Kazakh term "kazahstanec", not widely known outside Kazakhstan, refers to all citizens of the post-Soviet Republic of Kazakhstan, regardless of their ethnicity "nacional'nost" (Kazakh Kazakhstanis, Tatar Kazakhstanis, Ukranian Kazakstanis, etc.) (Davenel 2013). 


\section{Reconfiguration During the First Years of Independence}

Kazakhstan gained its independence following the collapse of the Soviet Union in 1991. To consolidate their newly acquired independence, the Republic of Kazakhstan attempted to respond to the territorial integrity and national security challenges resulting from demographic and ethno-geographic issues. However, the over dependence on the Russian economy led to an industrial and economic crisis (Fierman 1998).

After the country's independence there was a clear political mandate to "nationalize" the country. For instance, textbooks were revised to focus on Kazakhstan's history and the names of streets, squares, and cities were changed. Furthermore, state policy towards inter-ethnic dialogue was based on the primacy of the Kazakh culture and the conception of a "first culture among equals" (Davenel 2013). In this respect, the newly acquired independence from the Soviet Union allowed a reconfiguration of citizenship in Kazakhstan but maintained some Soviet practices of building national identity (Bozymbekova and Lee 2018).

Between 1992 and 1993, Kazakhstan set up a program to repatriate Kazakh exiles from neighboring countries such as Mongolia, China, Iran, Turkey, Russia and Tajikistan. This program was later followed by the "Kazakhstan 2030" strategy to strengthen the demographic weight of the country and address the demographic crisis linked to the departure of Russians and Germans. In various speeches, former President Nazarbayev evoked a population goal of 20 million people in 2015 and 25 million in 2030. To achieve this ambition, he called for the repatriation of the Oralmans (ethnic Kazakhs who fled the current Kazakh territory in the nineteenth century and during the Stalinist period). This resulted, among other things, in the 1998 Migration Act, which provided for the establishment of an incentive policy composed of financial and social aid. ${ }^{4}$ (Seys 2009).

During this period, the demographic dynamics meant that the Kazakh people finally represented the majority of the population. The proportion of Kazakhs grew from 39.6\% to 59.8\% from 1989 to 2007 while those of Russians and Germans fell respectively from $37.8 \%$ to $25 \%$ and $5.8 \%$ to $1.4 \%$ (Seys 2009).

In this context, we can speak of a "soft reconfiguration" of citizenship that did not result in clashes or ethnic conflicts. It seems that the open character of the Kazakh people allowed this smooth evolution. In fact, ancestral nomadic culture is characterized by welcoming and solidarity towards all groups despite their cultural differences or historical wounds. To survive in a hostile physical environment, Kazakh nomads considered it imperative to foster mutual aid and openness to others.

Nevertheless, in the first phase after independence, many non-Kazakh ethnic groups who previously identified with the Soviet Union experienced deep psychological malaise and many of them did not want their ethnicity to be specified in official documents (Ahmetzanova 1998).

\footnotetext{
${ }^{4}$ The aid consists of $600 €$ per adult (plus $€ 300$ for transport), priority access to housing and land in rural areas as well as social benefits provided the person renounces their current citizenship and applies for naturalization.
} 
Today, the ethnic composition of Kazakhstan is: $70.23 \%$ Kazakh, $19.96 \%$ Russian, 3.32\% Uzbek, $1.31 \%$ Uyghur, $0.11 \%$ Tatar, $1 \%$ German, and less than $1 \%$ Korean, Turkish, Azerbaijani, etc. (Committee on Statistics 2019). The percentage of ethnic Kazakhs has gradually increased from $63.1 \%$ in 2009 to $70 \%$ in 2019 (Central Intelligence Agency 2014).

A national survey aimed at investigating the issue of ethnic and civic identity found that $75.1 \%$ of the respondents cite civic identity as the most important form of self-identification. However, the study shows that ethnic Kazakhs have a higher level of ethnic self-identification than other groups (61\% of ethnic Kazakhs compared to $51 \%$ of Russians and $43 \%$ other ethnic groups) (Aitymbetov et al. 2015).

Overall, unlike many post-Soviet republics, such as Armenia or Turkmenistan, we can see that Kazakhstan remained a multi-ethnic state. According to Ahmetzanova (1998), the country promotes Kazakh ethnic identity revitalization but nevertheless maintains a strong multi-ethnic identity unlike other national contexts where mono-ethnic identity is dominant:

The Kazakh state had to establish a new identity policy upon which it could build its legitimacy, satisfying both nationalist groups looking for more radical changes and calming the fears of the massive Slavic population who had long lived in the republic. The authorities discussed whether they would choose to develop a civic nationhood as a state for all of its citizens, irrespective of their ethnic background, to build a binational or multinational state, seen as a state with two or more "core" nations, or, finally, to embark on a revenge-inspired nationalist agenda in favor of the main or "titular" nation (Sharipova et al. 2017, p. 221).

However, issues related to ethnic, civic and national identity have been subject to many debates since the country's independence and representatives of various ethnic groups have placed more importance on ethnic identity since the fall of the Soviet Union (Kuškumbaev 2011). Consequently, the ethnically diverse population of Kazakhstan presented a great challenge for the new political regime. In this context, postcolonial political discourse and ideological slogans in Kazakhstan become tools for the regime's legitimation and the growing national-patriotic movement fighting mass "Russification" and the loss of the Kazakh language and values (Kudaibergenova 2016).

The elites of Kazakhstan fear an ethnicization of economic and social policies and have pushed Kazakh leaders to gradually introduce into the statutes the principle of the sovereignty of the republic.

Kazakhstan has therefore implemented policy to manage cultural diversity and adopted laws to regulate the linguistic and cultural claims of the various national groups. The constitution of Kazakhstan recognizes the rights and freedoms of citizens to express their cultural and linguistic diversity in accordance with Article 7, paragraph 3 of the Constitution which states: "The State shall promote conditions for the study and the development of the languages of the peoples of Kazakhstan" (Republic of Kazakhstan 2019, para. 7) and Article 14, paragraph 14 which affirms that "No one shall be discriminated against because of their origin, social status, status, activity, sex, race, nationality, language, attitude to religion, belief, place of residence or other circumstances" (Republic of Kazakhstan 2019, para. 14). In this respect, national minorities are expected to respect the traditions and customs of Kazakhs without losing their own. 
Today, Kazakhstan's multicultural society recognizes each ethnic group's right to maintain their native culture while respecting those of others. Each ethnic group is allowed to organize their national holidays or celebrate events such as marriages according to their own traditions. Priority is given to friendship, mutual understanding, tolerance and consent. An example that illustrates the respect for diversity in Kazakhstan is the Nauryz celebration during which different ethnic groups prepare their national dishes and perform traditional dances and songs.

This friendship between the ethnic groups of Kazakhstan is represented at the State level:

1. The Assembly of Peoples of Kazakhstan, created following the initiative of the First President of the Republic of Kazakhstan Nursultan Nazarbayev, was tasked with spreading the idea of the spiritual unity and friendship of the peoples of the country. Nine representatives to the Kazakhstan Parliament can be elected from the Assembly of the People of Kazakhstan.

2. More than 1500 ethnic cultural centers and ethno-cultural associations are present throughout the country, to preserve cultural heritage and display different cultures. The activities of national communities are supported by the state.

3. In Kazakhstan, exhibitions on ethnic cultures are regularly organized as well as international competitions and ethnic culture festivals with the support of the government. There are also reputable German, Uyghur and Korean theaters.

Despite these initiatives, disparities exist between ethnic groups which are unequal in size and political and economic power (Davenel 2013). Consequently, the interests and demands of different ethnic groups diverge on matters related to official state languages and educational policies; demographic and migratory problems; regional development; control of economic resources; advantages granted to minorities; representation in the legislative and executive branches of power; and even foreign policy (Kuškumbaev 2011).

It seems that interethnic relations in Kazakhstan are not divisive, but that does not mean that they are free from problems concerning the distribution of economic wealth and the status and prestige of certain languages. According to Davenel (2013), there are three main categories of discourse relating to ethnic minorities circulating in Kazakh society: many members of the elite promoting multiple reethnification; officials of cultural centers of national minorities denouncing discrimination; and both scientists and the first President Nazarbayev disputing that minorities are discriminated against because of their national allegiance.

\section{Current Issues of Citizenship in the Context of Globalization}

In the current context of globalization, social relations and the nature of citizenship are changing in Kazakhstan. After 30 years of independence, the current issues of citizenship are multiple and largely affected by globalization. The question of a new 
sense of national identity leads to broader implications regarding modern nationbuilding processes and the constraints of the government's constructivist nationbuilding policies (Sharipova et al. 2017).

Firstly, Kazakhstan has embarked on economic and political modernization of its economy and an opening up to international investments. The volume of these investments, particularly in the mining and petroleum sectors, has increased significantly and generated some economic prosperity. Kazakhstan has made enormous strides since the collapse of Soviet Union, and is now categorized as an upper middle-income country. GDP-Gross Domestic Product grew at a rate of $9 \%$ between 2000 and 2007 before dropping in 2008 and 2009, then rapidly recovering in 2010. As a result, there has been a dramatic reduction in official poverty rates, from $39 \%$ in 1998 to 3.8\% in 2012, and a decline in unemployment rates (Blum 2016).

This modernization has also resulted in an openness to Western countries even if ties to Russia remain strong. The context of increasing globalization in Kazakhstan has seen the emergence of a middle class and increased consumerism, especially in urban centers where shopping malls, fashionable cafés and shops have sprung up which are "either explicitly Western or monolithically 'global' in the sense they exude modernity without any specific geographical character" (Blum 2016, p. 8). Furthermore, openness to the world has been encouraged by providing scholarship for international education and access to the Internet, and through the promotion of the English language.

Secondly, globalization and economic growth has brought new international migratory flows. This new influx of migrants has given rise to some tensions with the Kazakh population. In 2005, official statistics showed that a total of 74,807 people immigrated to Kazakhstan: $88 \%$ of which have immigrated from the Commonwealth of Independent States of the former USSR (60\% of which are from Uzbekistan) (Seys 2009).

Thirdly, Kazakhstan is experiencing a revival of the Muslim religion, which had been suppressed by the Soviet regime. External signs of Muslim religiosity are multiplying in the public space, provoking a reaction from the State, anxious to preserve civil peace and religious freedom. The political debate is expected to resurge in the years to come on interethnic and interfaith relations, political participation of citizens and decentralization strategies.

Finally, while recognizing that the process of rebuilding citizenship and national identity has been relatively peaceful in Kazakhstan compared to other places in the world, underlying tensions should not be underestimated. An illustration of this is the successive changes in the alphabet used for the Kazakh language from Arabic to Cyrillic, to Latin in less than a century (Michelotti 2016) as well as the choice of the capital city reflecting a geopolitical search for stability in the country. The capital of Kazakhstan was Orenburg until it was attached to Russia. Kizilorda then became the capital in 1924 but was later moved to Almaty in the South in 1928. In 1997, after the country's independence, Kazakhstan decided to move the capital once more to Akmola, situated in an agricultural region rich in natural resources and benefiting from a strategic geopolitical position. Later, the city was renamed Astana, which means capital in Kazakh (Fierman 1998; Arslan 2014). In 2019, the capital's name 
changed once again to Nur-Sultan, in reference to the former president of Kazakhstan.

The rebuilding of citizenship and national identity has revealed tensions within the Kazakhs zhuz and their respective positions within the elite population and the state bureaucracy have significantly evolved since independence. Schatz (2000, 2005) analysis shows that the Great zhuz has been disproportionately represented in state bureaucracy compared to their demographic weight, with the Small zhuz is continually relegated to the weakest position. This could be partially attributable to the physical distance between the west of the country and the Soviet-era capital of Almaty. Great and Middle zhuz members have been generally better educated and trained since the Soviet period (for example, the former and the current presidents belong to the Great $z h u z$ ). Although initially excluded to some degree from power, the Middle $z h u z$ has allied itself with the Great $z h u z$, prompting the relocation of the capital city from Almaty in Great zhuz territory to Astana in Middle zhuz territory, and the significant incorporation of Middle zhuz members into state power structures.

\section{Trilingualism as a Perspective of Global Citizenship in Kazakhstan}

In this last section, we will discuss the role and status of languages in Kazakhstan and how they might shape Kazakh citizenship in the context of globalization in the years to come. Indeed, multiculturalism is a feature of Kazakh cultural and linguistic identity and opens up opportunities for global citizenship education (GCE). However, language issues, especially regarding the knowledge and usage of Kazakh remains a highly controversial and sensitive political topic. Although Kazakh is an official state language and the language of the predominant ethnic group, it still lags behind Russian in terms of everyday use since many people, including many urban Kazakhs, lack Kazakh-language proficiency (Sharipova et al. 2017).

The Kazakh political elite is constantly striving to find consensus in order to revive and perpetuate the use of the Kazakh language and culture within the existing legal framework, while trying at the same time not to restrict the interests and rights of other non-Kazakh ethnic groups. This delicate posture may carry a risk of interethnic misunderstanding (Èsment 1999).

This issue is directly related to the former Soviet government's fight against illiteracy and its "Russification" policy (Turumbetova et al. 2019). Under the Soviet regime, illiteracy was defined as a lack of knowledge of the Russian language and proficiency in Russian was required for access to higher education (Suleimenova 2011).

Following independence, language policies changed and Kazakhstan became a multilingual country. Today, Kazakh is spoken by $52 \%$ of the population and is the official language of the state. Russian nevertheless remains an official language 
(Republic of Kazakhstan 2019) and is spoken by almost all citizens in the country, making it the lingua franca between the different ethnic groups and a dominant language in the media. The legal framework in Kazakhstan clearly establishes the status of each language (Zhumanova et al. 2016). Kazakh is recognized as the state language and is used for state management, legislation, legal procedures and bureaucracy in all spheres of social relations throughout the country. Furthermore, it is every citizen's obligation to acquire the state language. To do so, the government and all public institutions are required to strengthen the Kazak language by reinforcing its international authority and developing organizational, material and technical conditions to access free state language learning as well as promoting Kazakh learning among the diaspora.

Today, the 2011-2020 trilingual educational policy aims to develop fluency in Russian, Kazakh and English as well as promoting other languages (Zhumanova et al. 2016). The Kazakh Government's Cultural Project "Trinity of Languages" aims to strengthen Kazakh as the state language, Russian as the language of interethnic communication and English as the language of successful integration into the global economy (Zhekibaeva et al. 2018). This multicultural approach relates to integration and the desire to create a society in which interpersonal and inter-ethnic relations are encouraged as well as the spiritual growth of the nation.

Nevertheless, tensions between languages remain within the educational system. In theory, students can choose among the various programs offered in Kazakh, Russian, English, or other minority languages. The proportion of students who follow a particular program depends on the ethnic composition of their region. Thus, in the mainly Russian-speaking regions of the North, most programs are in Russian, while in the south of the country, teaching in Kazakh dominates. This system, which tolerates the use of different languages in education, means that many Russianspeakers do not practice Kazakh and feel culturally closer to Russia than to Kazakhstan.

It seems therefore, that Kazakhstan's tolerance has produced parallel linguistic practices even though most Kazakhs are more or less proficient in Russian. It is hoped that in the future the attractiveness of bilingual or trilingual schooling can be improved. This will result in fluid or hyphen cultural and language identities.

Rees and Williams (2017) suggest that despite the Assembly of People's rhetoric on cultural and ethnic diversity, there are still significant barriers to citizen-level adoption of a supra-ethnic identity in Kazakhstan, particularly regarding language. However, many people claim an association with Kazakhstani identity, especially those who strongly value civic behavior rather than ethnic belonging.

In this respect, the construction of a new nation in Kazakhstan needs to articulate ethnic diversity and national unity:

The nation is a modern construct. It is imagined. So, it depends on whether we want to imagine a nation along more ethnic-genealogical lines, which makes it more exclusive, or to imagine a nation along more civic-territorial lines that treats all, regardless of ethnic, religious or regional background, equally. We support the latter, which would lead to more inclusive nation building (Loh 2017, p. 428). 


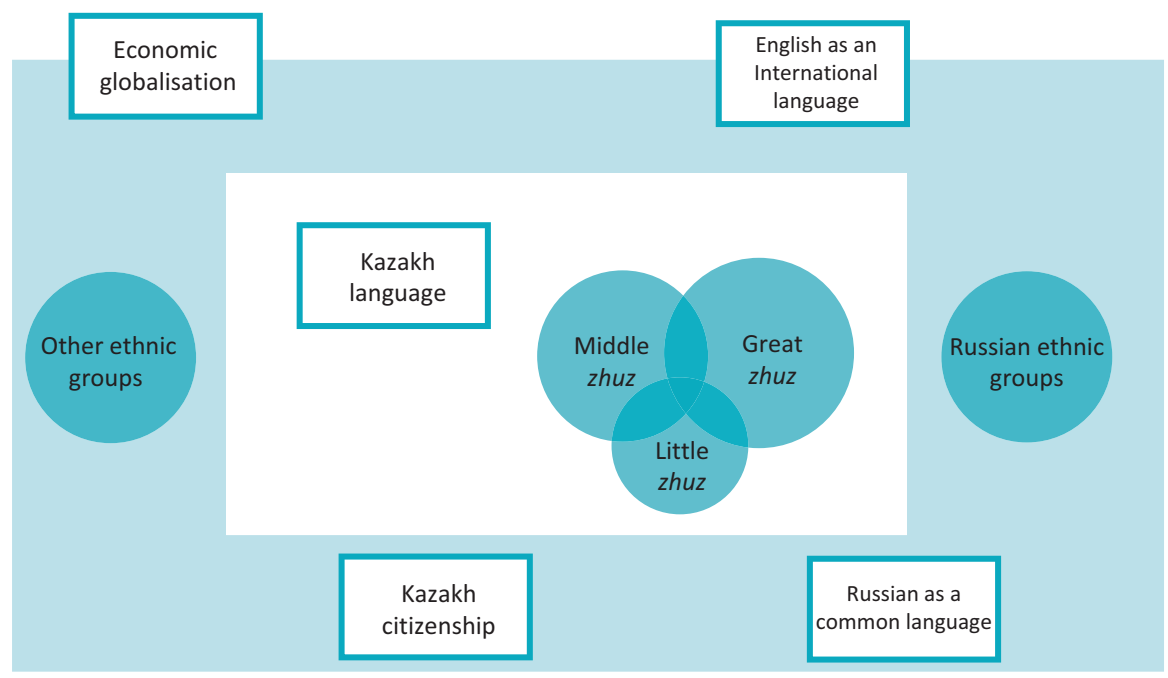

Fig. 5.1 Dimensions of citizenship in Kazakhstan

The ensuing Fig. 5.1 summarizes the current challenges of citizenship in Kazakhstan. In addition to the ethnic division of Kazakh people into three main zhuz, the Soviet era bought a new set of ethnic-language diversity, and today economic globalization creates a need for the English language.

Within Kazakhstan's complex citizenship model, Ordabayeva (2017) stresses the need to integrate global awareness into school curricula; encourage professional development for teachers and recognize the importance of administrative leadership in teaching GCE.

\section{Conclusion}

We want to conclude this text by reflecting on the global thoughts of the Kazakh philosopher Al-Farabi and on how to implement GCE in Kazakhstan.

Al-Farabi, known in the Western world as Alpharabius (872-951), was a renowned philosopher and jurist who wrote about political philosophy, metaphysics, ethics and logic. He was also a scientist, cosmologist, mathematician and music scholar. In the Islamic philosophical tradition, he is given the honorific title of "the Second Teacher", Aristotle being known in the East as "the First Teacher". He is credited with preserving the original Greek texts during the Middle Ages because of his commentaries and treatises, and with influencing many prominent Islamic philosophers, like Avicenna and Maimonides. Through his work, he became well known in the East as well as the West (Rescher 1962; Reisman 2005). 
Al-Farabi, tried to identify the characteristics of a virtuous city by systematically identifying the impediments to achieving happiness. He concluded that a virtuous city is the opposite of an ignorant and immoral one. Deducing that it is built on cooperation among its citizens:

The goal of education is to lead individuals to perfection since human beings were created for this purpose. The perfect human being (al-insan al-kamil), thought Al-Farabi, is the one who has obtained theoretical virtue - thus completing his intellectual knowledge—and has acquired practical moral virtues - thus becoming perfect in his moral behavior. Crowning these theoretical and moral virtues with effective power, they are anchored in the souls of individual members of the community when they assume the responsibility of political leadership, thus becoming role models for other people (Tanabayeva et al. 2015, p. 126).

Al-Farabi educational theory is based on a pedagogy of proximity allowing learners to move from individuals to citizens (Abdul-Jabbar 2020). We argue that GCE in Kazakhstan should take inspiration from the work of Al-Farabi who believed that 'knowledge without upbringing, without a moral beginning, can bring harm, not good'. The own biography of Al-Farabi pointed out the he was a global nomad thinker living and working in different countries and languages. As suggested by Günther (2006), Al-Farabi was among the first Muslim scholars to suggest an integrated curriculum for the higher learning of both the foreign and religious sciences, with the foreign being those grounded in Greek philosophy and science and the religious being those based on Islamic tradition.

Finally, GCE cannot ignore the fact that the construction of citizenship in Kazakhstan is an unfinished process because of its recent history and the rapid changes experienced in recent decades. This chapter shows that the tensions around citizenship are centered on the imperative of a Kazakh ethnic renaissance and the need to maintain the linguistic and fragile plurality that has characterized the country since independence. The use of English and the new importance given to Mandarin may require new identity configurations. Finally, the political changes of 2019 towards a more democratic political transition may also lead to uncertainties about the fragile ethnic-language balance in Kazakhstan.

\section{References}

Abdul-Jabbar, W. K. (2020). An intercultural encounter with Al-Farabi's pedagogy of proximity (Ittisal). In T. Strong-Wilson, C. Ehret, D. Lewkowich, \& S. Chang-Kredl (Eds.), Provoking curriculum encounters across educational experience: New engagements with the curriculum theory (pp. 116-129). New York: Routledge.

Ahmetzanova, G. K. (1998). Graždanskaâ identifikaciâ i opyt nezavisimoj gosudarstvennosti. Gosudartsvo i političeskie partii: istoriâ $i$ sovremennost. Almaty: PNEK, KISI.

Aitymbetov, N., Toktarov, E., \& Ormakhanova, Y. (2015). Nation-building in Kazakhstan: Kazakh and Kazakhstani identities controversy. Bilig, 74, 1-20.

Arslan, M. (2014). The significance of shifting Capital of Kazakstan from Almaty to Astana: An Evalution on the basis of geopolitical and demographic developments. Procedia-Social and Behavioral Sciences, 120, 98-109. 
Bakitov, A., \& Jumanova, R. (2016). Guide de conversation kazakh-français et français-kazakh. Sarrebruck: Éditions Universitaires Européennes.

Blum, D. W. (2016). The social process of globalization: Return migration and cultural change in Kazakhstan. Cambridge: Cambridge University Press.

Bozymbekova, K., \& Lee, J. C. K. (2018). Change and continuity in nation-building and citizenship education in Kazakhstan. Educational Practice and Theory, 40(2), 29-54.

Central Intelligence Agency. (2014). Kazakhstan. In The World Factbook 2013-14. Retrieved from https://www.cia.gov/library/publications/the-world-factbook/geos/kz.html

Committee on Statistics. (2019). Demographic statistics. The population of the Republic of Kazakhstan by individual ethnic groups at the beginning of 2019. Astana: Committee on Statistics of the Ministry of National Economy of the Republic of Kazakhstan.

Davenel, Y.-M. (2013). Renouveau culturel et diversité nationale au Kazakhstan. Paris: Editions Pétra.

Èsment, B. (1999). Problemy russkih Kazahstana: ètničnost' ili politika ? Diaspory, 2(3), 169-187.

Fierman, W. (1998). Language and identity in Kazakhstan: Formulations in policy documents 1987-1997. Communist and Post-Communist Studies, 31(2), 171-186.

Grousset, R. (1970). The empire of the steppes: A history of Central Asia. New Brunswick: Rutgers University Press.

Günther, S. (2006). Be masters in that you teach and continue to learn: Medieval Muslim thinkers on educational theory. Comparative Education Review, 50(3), 367-388.

Kudaibergenova, D. T. (2016). The use and abuse of postcolonial discourses in post-independent Kazakhstan. Europe-Asia Studies, 68(5), 917-935.

Kuškumbaev, S. (2011). L'identité ethnique et la politique d'intégration sociale au Kazakhstan. Cahiers d'Asie centrale, 19-20, 465-469.

Loh, F. K. W. (2017). Ethnic diversity and the nation state: From centralization in the age of nationalism to decentralization amidst globalization. Inter-Asia Cultural Studies, 18(3), 414-432.

Massanov, N., Abylkojin, J., Yerofeeva, I., Alekseenko, A., \& Baratova, G. (2000). Histoire du Kazakhstan. Les ethnies et les cultures. Almaty: Daik-Press.

Michelotti, V. (2016). Переходное время: Alphabet reform and identity politics in modern Kazakhstan. Al-Farabi, 2.

Olcott, M. B. (1995). The Kazakhs. Stanford: Stanford University Press.

Ordabayeva, Z. (2017). The role of curriculum in teachers' understanding of global citizenship education in one public school in Akmola region, Kazakhstan. Doctoral dissertation, Nazarbayev University Graduate School of Education.

Rees, K. M., \& Williams, N. W. (2017). Explaining Kazakhstani identity: Supraethnic identity, ethnicity, language, and citizenship. Nationalities papers, 45(5), 815-839.

Reisman, D. C. (2005). Al-Farabi and the philosophical curriculum. In P. Adamson \& R. C. Taylor (Eds.), The Cambridge companion to Arabic philosophy (pp. 53-71). Cambridge: Cambridge University Press.

Republic of Kazakhstan. (2019). The constitution of the Republic of Kazakhstan. Retrieved from: http://www.akorda.kz/en/official_documents/constitution

Rescher, N. (1962). Al-Farabi: An annotated bibliography. Pittsburgh: University of Pittsburgh Press.

Schatz, E. (2000). The politics of multiple identities: Lineage and ethnicity in Kazakhstan. EuropeAsia Studies, 52(3), 489-506.

Schatz, E. (2005). Reconceptualizing clans: Kinship networks and statehood in Kazakhstan. Nationalities Papers, 33(2), 231-254.

Seys, F. O. (2009). Les dynamiques démographiques au Kazakhstan, un modèle spécifique depuis l'indépendance. Espace populations sociétés. Space populations societies, 2, 243-261.

Sharipova, D., Burkhanov, A., \& Alpeissova, A. (2017). The determinants of civic and ethnic nationalisms in Kazakhstan: Evidence from the grass-roots level. Nationalism and Ethnic Politics, 23(2), 203-226.

Suleimenova, E. (2011). Languages processes and politics. Almaty: Kazakh University. 
Tanabayeva, A., Massalimova, A., Mukhatova, O., Alikbayeva, M., \& Alikbayeva, Z. (2015). Al-Farabi's humanistic principles and "virtuous city". The European Proceedings of Social \& Behavioural Sciences, 15405, 124-129.

Turumbetova, L., Manabayev, B., \& Shayakhmetov, O. (2019). Kazakhstan education system breakthrough, having overcome the tragic events in the history of Kazakh people. Journal of Oriental Studies, 1(88), 152-161.

Zardykhan, Z. (2002). Kazakhstan and Central Asia: Regional perspectives. Central Asian Survey, 21(2), 167-183.

Zhekibaeva, B. A., Kairbekova, B. D., \& Zobnina, I. E. (2018). On the status of the Kazakh, Russian and English languages in the education system of the Republic of Kazakhstan. Қараванды университетінің хабаршысы. Педагогика сериясы. $=$ Вестник Карагандинского университета. Серия Педагогика. (Bulletin of the Karaganda University), (2), 111-116.

Zhumanova, A. Z., Dosova, B. A., Imanbetov, A. N., \& Zhumashev, R. M. (2016). Language politics in the Republic of Kazakhstan: History, problems and Prospect. International Journal of Environmental and Science Education, 11(11), 4241-4253.

Open Access This chapter is distributed under the terms of the Creative Commons Attribution 4.0 International License (http://creativecommons.org/licenses/by/4.0/), which permits use, duplication, adaptation, distribution and reproduction in any medium or format, as long as you give appropriate credit to the original author(s) and the source, a link is provided to the Creative Commons licence and any changes made are indicated.

The images or other third party material in this chapter are included in the work's Creative Commons licence, unless otherwise indicated in the credit line; If such material is not included in the work's Creative Commons licence and the respective action is not permitted by, users will need to obtain permission from the license holder to duplicate, adapt or reproduce the material.

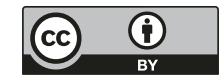

